\title{
REMEDIES FOR THE CRISIS AND CORONAVIRUS-INDUCED INSOLVENCY: WHAT LEGAL "WEAPONS" ARE AVAILABLE TO FIGHT THIS "WAR"?
}

\author{
Maria Margherita Lazzara \\ Researcher of Economics Law \\ Department of Economy and Business \\ Catania University \\ Email: mlazzara@lex.unict.it
}

Italy

\author{
A R T I C L E I N F O \\ Article history: Article \\ Received \\ Revised \\ Accepted: 16 October, 2020 \\ DOI: 10.47742/ijbssr.v1n2p4
}

\author{
Vol: 1, Issue: 2 \\ October $/ 2020$ \\ https://ijbssrnet.com/index.php/ijbssr \\ DOI: 10.47742/ijbssr.v1n2p4
}


Based on the legislation adopted as a matter of urgency in these past few days by the Italian government, we would like to afford some food for thought as well as some solutions for the considerable problems that the health emergency has already posted and will continue to pose shortly for enterprises and consumers unable to meet their payment obligations.

In our view it is urgent, and thus can no longer be postponed, to develop the first line of intervention able to read and pro-actively "to filter" the crisis suffered at the individual level: "viable debtors, honest entrepreneurs, and other natural persons".

Moreover, a second action plan should, prospectively, look to the system. There is an urgent need to define a specific regime, a "special" regulatory framework for enterprises in the time of Covid-19. Just as Coronavirus patients need to be isolated from other patients, arranging for health facilities "dedicated" to their care and separated from common facilities, it is paramount to identify "system" solutions by providing for a set of dedicated tools for "infected" enterprises and for over-indebted households as a result of the measures adopted by the Government to contain the pandemic.

\section{Italian legislative remedies adopted from March to July}

In this extremely delicate macroeconomic scenario, in these past few months, numerous legislative provisions have been issued that contain an array of temporary measures impacting substantive, bankruptcy, and corporate law. Especially drastic remedies have been adopted, defined as "instances of law of war issued in times of peace".

\section{In a nutshell, it is worth mentioning the following:}

- Legislative Decree no. 9 of 2 March 2020 and Legislative Decree no. 11 of 8 March 20207 , respectively providing the suspension of procedural time-limits; the suspension of the mandatory, legal and conventional, substantive and procedural time-limits, entailing prescriptions and forfeitures, as well as time frames for the fulfillment of contractual obligations. The time-limits relative to executive processes and insolvency procedures, as well as the time frame for the notification of the official reports, for the execution of reduced payment, for carrying out defense activities, and for the submission of legal appeals have also been suspended, for the same period and vis-à-vis the same individuals.

- Law no. 27 of 24 April $2020^{8}$ chiefly addresses the responsibility of the debtor, namely the incidence of the emergency in appraising the conduct of the debtor responsible for meeting his/her obligation; effectively providing for a cause of exclusion, by law, of fault on the debtor's part;

- Law no. 40 of 5 June $2020^{9}$ providing, first of all, for the postponement of the entry into force of the new Italian Code of Enterprise Crisis and Insolvency to September 2021. It is prescribed the suspension of the deadlines of the fulfillment of Agreements with Creditors (Concordati preventivi) and of the approved Restructuring Agreements (Accordi di ristrutturazione), of the suspension of the deadlines for negotiable instruments, of the suspension of tax payments and contributions. It has been provided that appeals may not be pursued for the declaration of Bankruptcy (Fallimento) or Compulsory Administrative Liquidation (Liquidazione Coatta Amministrativa), for the ascertainment of the state of insolvency in the Extraordinary Administration of large enterprises in crisis (Amministrazione Straordinaria delle Grandi imprese in crisi) until 31 December 2020. Lastly, a gamut of provisions dedicated to Agreements with Creditors and approved restructuring Agreements is introduced $^{10}$. Specifically, to avoid termination of Agreements with Creditors and of Restructuring Agreements already approved or implemented between 23 February 2020 and 31 December 2021, a six-month extension has been provided for the deadlines of their fulfillment ${ }^{11}$.

All these interventions are merely aimed at "postponing" the consequences of the current crisis. Therefore, they can be viewed as "first aid measures" unsuitable for effectively facing what is referred to as "phase two" 12 . The instruments made available by the Italian legislator to date mostly consist of suspensory mechanisms operating at various levels and profiles of substantive, bankruptcy, and corporate law ${ }^{13}$. On the other hand, existing institutions must adjust more efficiently to the idea that economic time cannot stop because of the pandemic. Concentrating now solely on insolvency proceedings, it is useful to touch upon:

\footnotetext{
"Urgent measures for families, workers and businesses related to the epidemiological emergency from COVID-19 " and " Extraordinary and urgent measures to counter the epidemiological emergency from COVID-19 and contain the negative effects on judicial activity". Both decrees have lapsed, but the main provisions have been transferred, now, to the Law no. 27 of 24 April 2020.

8 "Conversion in law, with amendments, of the decree-law 17 March 2020, n. 18, containing measures to strengthen the National Health Service and economic support for families, workers and businesses connected to the epidemiological emergency from COVID-19. Extension of deadlines for the adoption of legislative decrees. "

9 "Conversion in law, with amendments, of the decree-law 8 April 2020, n. 23, containing urgent measures regarding access to credit and tax obligations for companies, special powers in strategic sectors, as well as health and work interventions, extension of administrative and procedural terms. "

10 In the Agreements with creditors (Concordati preventivi) and the Restructuring Agreements (Accordi di ristrutturazione), that are pending after February 23 2020, the debtor can obtain from the Court a new deadline (not exceeding 90 days) to offer a new plan of restructuration; it had to take into account of the financials rewards caused by the Covid-19.

It's not clear if this provision is referred only to the Agreement approved by creditors otherwise to the Agreement admitted by the Court but not voted yet by creditors.
}

${ }^{11}$ The extension afforded by the law does not require any application by the debtor or even any del Decreto Liquidità e il tema dell'insolvenza incolpevole, www.ilcaso.it, 21/04/2020.

${ }^{12}$ A strong recommendation is coming from the Executive Board of CERIL (Conference of European Restructuring and Insolvency Law) for all European legislators, https://know.cerved.com/news/covid-19-e-sostenibilita-delle-imprese/.

Un'approfondita disamina, che muove proprio dal rapporto CERIL, in G. CORNO, L. PANZANI, I prevedibili effetti del Coronavirus sulla disciplina delle procedure concorsuali, in IL CASO.it (25/03/2020).

13 The rules on capital reduction, preparing of the budget, social's financing are suspended. During the year 2020 are suspended also other legal duty: the articles $2446,2^{\circ}$ e $3^{\circ}, 2447$, 2482 bis, $4^{\circ}, 5^{\circ}$ e $6^{\circ}$, e 2482 ter, 2484, n. 4,2545 duodecies cod. civ. won't be applied. On equal terms, the prevision in the articles 2467 e 2497 quinquies cod. civ., related to the partner's financial, are suspended too. This statement can be a great tool that can be useful for sourcing new funds for enterprises. See, IRRERA - FREGONARA, La crisi d'impresa e la continuità aziendale ai tempi del coronavirus judicial decision, as referred: Ambrosini, La "falsa partenza" del Codice della Crisi, le novità

in www.ilcaso.it, 15 aprile 2020 
1) the postponement of the entry into force of the Italian Code of Enterprise Crisis and Insolvency -C.C.I.I.- (unlike the envisaged date - August 2020 - it shall come into force in September 2021);

\section{2) Bankruptcy petitions blocked until 30 June 2020;}

Hence, we can only endorse the decision to postpone the entry into force of the Code; it was essential to avoid the interpretative and procedural difficulties which probably would have arisen during the implementation phase of new institutions and rules yet to be fully proven. This enables the entrepreneurial world, the courts, and the operators in the sector to keep relying on well-known and well-established insolvency mechanisms ${ }^{14}$. However, as shall be elucidated presently, it would be useful to anticipate the operation of those rules in the Code of Crisis that only bring about a few ameliorative improvements to institutions already regulated in Bankruptcy law ${ }^{15}$.

Conversely, the choice to consider inadmissible the appeal for the declaration of bankruptcy or also for the ascertainment of the state of insolvency (even where proposed by the debtor himself!) does not appear to be commendable. The solution not even allowing for the self-represented bankruptcy of enterprises manifestly beyond recovery, possibly for reasons preceding the outbreak of the pandemic, was deemed as excessively drastic, but above all irrational: an unjustified obligation for those who already are over-indebted to continue their business activity ${ }^{16}$.

Regrettably, it may be observed that no ad hoc instruments functional to the asserted plan for overcoming the crisis are introduced. In our opinion, the truly dramatic aspect is that no difference is made between enterprises hit by the crisis as a result of the measures adopted for "Covid-19" and those already over-indebted due to other existing reasons ${ }^{17}$. The measures introduced are directed indistinctly at all enterprises experiencing difficulties, assuming that this situation is engendered by the pandemic. The identification of the origin of the crisis represents a profile, that appears to be a prerequisite, stemming from emergency legislation and which, instead, may under no circumstances be underestimated.

\section{Suggestions to find some remedies for enterprises and households.}

It is key, in the development of an effective recovery plan, to differentiate between legislation and the remedies to "cure" individuals indebted due to the measures for containing

\footnotetext{
${ }^{14}$ The significant novelty introduced by the new Code of Enterprise Crisis and Insolvency (Codice della Crisi d'Impresa e dell'Insolvenza - C.C.I.I.) is the so-called "Early Warning procedure" (Procedure di Allerta) -artt. 12 ss. C.C.I.I.-: a sophisticated normative system designed to a virtuous path by a surveillance system that allows for preventive procedures concerning restructuring. In this tough time of extensive defaulting and actual debt crisis, the application of the "benchmarks" -provided by the artt. 12-25 C.C.I.I.-, could cause the insolvency for the $1 / 3$ of the Italian enterprises.

${ }^{15}$ For this idea, Santangeli - Fabbi, Il (giusto) differimento, in ragione dell'emergenza, della entrata in vigore del Codice della crisi d'impresa e dell'insolvenza; ma è indispensabile che alcune norme entrino in vigore immediatamente, in Judicium, 2020.

${ }^{16}$ There are a few exception of this general rule that fixed the inadmissibility of the petition for the declaration of Bankruptcy a) the proposal by the debtor himself when insolvency don't depend on the Corona virus; b) the Bankruptcy petition is a result of a lack of preconditions for the Agreement with creditors (Concordato preventivo) -art. $162,2^{\circ} 1$. f.-, for the repeal of
}

the spread of Covid-19 and the insolvency procedures currently in force and targeting prior insolvencies or insolvencies generated for other reasons. A mandatory step for the legislator should have been (and should be, shortly) precisely that of not allocating any "safe conducts" for opportunistic behavior. To this end, it is necessary to provide valid instruments to ascertain the origin of the financial difficulties, building a surveillance system that allows for the early detection of over-indebtedness and, thus, to be able to make a realistic prognosis of recovery ${ }^{18}$

To enhance the provisions made to date by the legislator, it is pointed out, in any case, that through the generally estimated suspension of the time-limit for the fulfillment, the legislator has introduced an actual cause of exclusion, by law, of the fault on the debtor's part. Esteemed jurists claim that "force majeure" could be called upon for a reinterpretation of legislation of our bankruptcy law that defines the state of insolvency, the state of crisis and over-indebtedness, excluding the declaration of bankruptcy if failure to fulfill own obligations is determined by force majeure, namely by elements that, under their extraordinary and unpredictable nature, lead to an objective inability to fulfill ${ }^{19}$. Indeed, there is no doubt that the crisis or the insolvency caused by the lockdown, provided for to manage the health emergency, is in no way ascribable to the debtor and it is common knowledge that, for some time now, the legislative approach to over-indebtedness is universally aimed at safeguarding the "deserving" debtor facing financial deficit through no fault of his/her own.

This proposal, under the conditions specified hereinafter, might constitute a suitable response to the current situation and is also aligned with the so-called "philosophy of forgiveness" that is the legal heritage of all evolved legal systems at the European and global levels ${ }^{20}$. The "insolvent but honest" debtor is the "protagonist" of the aforesaid Directive (EU) 2019/1023; debt discharge for the "deserving" debtor, namely s/he who is heavily indebted because of a sudden and unforeseeable economic situation, is the go-to instrument to improve restructuring for a fresh start. In this respect, the Directive specifies the methods for ascertaining this status: under paragraph 79 is it stated that "in establishing whether an entrepreneur was dishonest, judicial or administrative authorities might take into account circumstances such as the nature and extent of the debt; the time when the debt was incurred; the efforts of the entrepreneur to pay the debt and comply with legal obligations, including public licensing requirements and the need for proper bookkeeping; actions on the

the Agreement -art. $173,2^{\circ}$ e $3^{\circ}$, 1.f- and reject the Court approval -art. $180,7^{\circ}$, 1. f.-; c) the Public Prosecutor ask declaration of Bankruptcy.

${ }^{7}$ For that reasons the Suisse Federal Office of Justice (COVID-19-Verordnung Justiz und Verfahrensrecht) is studyng a transitional regime with a "flexible" procedure characterised by the moratorium to assist small and medium-sized enterprises hit by the crisis for "Covid19"; www.bj.admin.ch/ejpd/it/home/news (2020-04-09 and 2020-04-16).

${ }^{8}$ On the legal concept of "recovery", to select the companies in financial ill-health, see, Minervini, Disciplina della crisi e diritto della concorrenza, in Riv. dir. comm, 2019, I, pag. 299 ss.

${ }^{9}$ See, Limitone, La forza maggiore nel giudizio sull'insolvenza, www.ilcaso.it, 2 aprile 2020 and Monticelli - Rosati, Il sole 24Ore, 24 aprile 2020.

${ }^{20}$ Let us refer to our work on this subject: Lazzara, Riflessioni sulla meritevolezza del consumatore, Rivista diritto fallimentare, 2017, II, pag. 1571 
entrepreneur's part to frustrate recourse by creditors; the fulfillment of duties in the likelihood of insolvency, which is incumbent on entrepreneurs who are directors of a company; and compliance with Union and national competition and labor law".

The second profile that is the focus of this paper aims to propose practical and effective measures to manage the financial difficulties of all those affected whose crisis is caused exclusively by the lockdown measures. Researchers are wondering if to alleviate the emergency, in terms of the entrepreneurial crisis, new, more rapid, and streamlined procedures may prove necessary as opposed to the existing ones which are more convoluted and detailed ${ }^{21}$.

I believe that appropriate instruments already exist in the provisions of the current Bankruptcy law and also in the new Code of Crisis, which could be appropriate for the economic situation with a few simple amendments that do not cause a crisis of rejection $^{22}$. Being aware of the sensitive nature of this subject, that undoubtedly requires greater in-depth inquiry, we would like to suggest an adaptation of existing legislation on Moratorium Agreement-under art. 62 C.C.I.I-, Confirmed Recovery Plans under Art. 56 C.C.I.I.- or Restructuring Agreements by possibly taking advantage of the improvements brought by the Code of Crisis to these procedures. In this respect, it suffices to cite the instance of the "Agreements with extended effectiveness" (art. 61 C.C.I.I.), or the possibility to renegotiate and modify a Recovery Plan already advanced according to art. 58 C.C.I.I...

Irrespective of the legislative choice, the simplified, essentially streamlined, swift, and flexible procedure must be characterized by the recurrence of some necessary elements: i) moratorium and debt discharge for the "faultless" debtor; ii) prohibition to open bankruptcy proceedings; iii) "protective measures" ensured, such as the blocking of enforcement actions of "automatic stay" creditors; iv) approval of creditors, possibly with an implicit favorable vote; v) facilitating measures for capitalization and financing; vi) support to corporate continuity ${ }^{23}$.

\footnotetext{
${ }^{21}$ See, inter alia, recently, Della Santina, Le discipline dell 'insolvenza e della crisi d'impresa ai tempi della pandemia da covid - 19. impressioni e spunti di riflessione, www.ilcaso.it, 1 aprile 2020.

${ }^{22}$ The moment of deep doubt that we are living in, require a particular caution from the ideas of estimeed jurists which suggest innovations and changes; they suggest to import measures from other system to use them in the insolvency proceeding, for instance the Technical Preventive Assessment (Accertamento Tecnico Preventivo -art. 696 Civil Procedural Code-), or the Support Administration for incapacitated people (Amministrazione di Sostegno -artt. 404-413 Civil Code-) or, furthermore, introduce again the old Controlled Administration (Amministrazione Controllata -repealed by the D.lgs. 6/2005-). See, Censoni, La gestione delle crisi sistemiche delle imprese da Covid-19 fra legge fallimentare codice della crisi e dell 'insolvenza: il ritorno dell 'amministrazione controllata?, www.ilcaso.it, 3 giugno 2020; Galletti, Il diritto della crisi sospeso e la legislazione concorsuale in tempo di guerra, www.ilfallimentarista.it, 15 aprile 2020.

${ }^{23}$ On this points esteemed jurists agrees, most recently: Ambrosini, La "falsa partenza" del codice della crisi, le novità del decreto liquidità e il tema dell 'insolvenza incolpevole , www.dirittobancario.it.; Fimmanò, La resilienza dell'impresa di fronte alla crisi da coronavirus mediante affitto d'azienda alla newCo-start up, auto-fallimento e concordato "programmati”, www.ilcaso.it, 1 april 2020; Leuzzi, Dalla crisi all'emergenza: la prededuzione al tempo del covid-19, www.ilcaso.it, 22 march 2020.
}

${ }^{24}$ Art.2, Directive EU 2029/1023 stating that “practitioner in the field of restructuring' means any person or body appointed by a judicial or administrative authority to carry out, in particular, one or more of the following tasks: (a) assisting the debtor or the creditors in drafting or negotiating a restructuring plan; (b) supervising the activity of the debtor during http://iarpnet.org/

To tackle the crisis in a pro-active manner without further increasing, in these difficult times, the burden on the judiciary, these "simplified" procedures could be entrusted to specialized sections in Courts, possibly by appointing honorary judges and lay judges endowed with specific legal or economic and corporate expertise ${ }^{24}$. Likewise, the idea is widely accepted of entrusting their management to existing Organisms such as Italian O.C.C. (Crisis Management Organism, Law no. 3 of 27 January 2012) or the established Italian O.Cri. (Crisis Organism, Art. 2, lett. u), C.C.I.I. ${ }^{25}$ ), possibly under the supervision of the Chambers of Commerce.

The Italian government, rather than indiscriminate allround distribution financing and bonus "to rain", should have to support the procedural costs and pay the "manager of crisis" to assist the debtor over-indebtness and to negotiate a restructuring Plan among creditors ${ }^{26}$. This idea appears to be in line with the compatibility conditions sets out by the Commission -at $\S 3$ - to apply to the aid granted by the Member States under Article 107(3)(b) TFEU $^{27}$.

This proposal appears to be perfectly in line with all the principles of the aforementioned Directive (EU) 2019/1023 aiming to strengthen, in Europe, a culture of recovery of enterprises in difficulty as a "preventive" measure. In this directive it is stated that "to promote efficiency and reduce delays and costs, national preventive restructuring frameworks should include flexible procedures, Member States should be able to limit the involvement of judicial or administrative authorities to situations in which it is necessary and proportionate while taking into consideration, among other things, the aim of safeguarding the rights and interests of debtors and of affected parties, as well as the aim of reducing delays and the cost of the procedures."

All States seem to be following this path by arranging for preventive restructuring frameworks taking place out of court, informal restructuring based on contractual agreements, and building a surveillance system that allows for the early detection of over-indebtedness. ${ }^{28}$

the negotiations on a restructuring plan, and reporting to a judicial or administrative authority; (c) taking partial control over the assets or affairs of the debtor during negotiations". ${ }^{25}$ Interesting legislative proposal comes from the Scientific Committee of C.R.I.S.I. (Centro Ricerca Interdipartimentale Impresa Sovraindebitamento Insolvenza) for a "Simplified procedure of crisis assisted settlement" (Procedura semplificata di composizione assistita della crisi); it's specified an Organism more streamlined than the O.Cri., actually required by the artt. 16 ss. C.C.I.I., www.ilcaso.it, 7 maggio 2020.

${ }^{26}$ Among other, see DI CECCO, Spunti per una riflessione collettiva sulle misure adottate ed adottabili per il contrasto alla crisi economica da pandemia, www.ilcaso.it, 3 may 2020; GARESIO, Alla ricerca della liquidità perduta. prime considerazioni sulle misure di sostegno alle imprese e sui loro possibili impatti sui

ratios patrimoniali delle banche, www.ilcaso.it, 17 april 2020; GOBBI, PALAZZO -

SEGURA, Le misure di sostegno finanziario alle imprese post-covid-19 e le loro implicazioni di medio termine, www.bancaditalia.it.

${ }^{27}$ In the Communication (Temporary Framework for State aid measures to support the economy in the current COVID-19 outbreak 2020/C 91 I/01) it is enounced that "Member States must therefore show that the State aid measures notified to the Commission under this Communication are necessary, appropriate and proportionate to remedy a serious disturbance in the economy of the Member State concerned and that all the conditions of this Communication are fully respected".

${ }^{28}$ In Spain was adopted the "Real Decreto-Ley 08/2020 de 17 de Marzo 2020 e 16/2020, de 28 de abril, de medidas procesales y organizativas para hacer frente al COVID-19 en el ámbito de la Administración de Justicia”. Among many : Gerbaudo, La respuesta del derecho concursal de Espana frente a la Pandemia Covid-19. Noticia del Real Decreto 28 abril 2020, n. 16, Seminario 27 mayo Universitad national de Rosario; Regueriro, Las reformas sobre 
Vol: 1, Issue: 2

October $/ 2020$

https://ijbssrnet.com/index.php/ijbssr DOI: 10.47742/ijbssr.v1n2p4

\section{Conclusions.}

Since it is impossible to grasp the present without looking back to the past or ahead to the future, I would like to conclude by stressing that the Italian Civil Code (Royal Decree no. 262 of 16 March 1942) and, for all that falls within our remit, the Bankruptcy Law itself (Royal Decree no. 267 of 16 March 1942), were drawn up and outlined in time of war within a historical and economical context of critical worldwide crisis; yet, the foresight of so many regulations has meant that these have remained unchanged to this day. Suffice to say that the notion of "insolvency" of the Bankruptcy Law of 1942 has been transferred without any amendments to art. 2 of the new Italian Code of Enterprise Crisis and Insolvency. Given the observations made by those who perceive, in the Coronavirus pandemic, the same devastating effects of a war-like situation, a correspondence is noted precisely with the new Italian Code of Enterprise Crisis and Insolvency. This legislative corpus, developed during a serious economic downturn, shall also be able to operate in an emergency context. Our legislative history leads us to confide in the ability of the Italian legislator to pinpoint recovery solutions; solutions also lasting in the medium-long term if the "protection" needs of indebted individuals and the interest of creditors in not having their rights affected can be suitably balanced. In conclusion, the difficult challenge of the legislator will be to successfully envisage concrete opportunities for a fresh start, without being indulgent towards any opportunistic behavior.

\section{References:}

CERIL (Conference of European Restructuring and Insolvency Law) for all European legislators, https://know.cerved.com/news/covid-19-e-sostenibilita-delle-imprese/;

DI CECCO, Spunti per una riflessione collettiva sulle misure adottate ed adottabili per il contrasto alla crisi economica da pandemia, www.ilcaso.it, 3 may 2020;

Fimmanò, La resilienza dell'impresa di fronte alla crisi da coronavirus mediante affitto d'azienda alla newCo-start up, autofallimento e concordato "programmati", www.ilcaso.it, 1 april 2020;

GARESIO, Alla ricerca della liquidità perduta. prime considerazioni sulle misure di sostegno alle imprese e sui loro possibili impatti sui ratios patrimoniali delle banche, www.ilcaso.it, 17 april 2020;

GOBBI, PALAZZO - SEGURA, Le misure di sostegno finanziario alle imprese post-covid-19 e le loro implicazioni di medio termine, www.bancaditalia.it;

Gerbaudo, La respuesta del derecho concursal de Espana frente a la Pandemia Covid-19. Noticia del Real Decreto 28 abril 2020, n. 16, Seminario 27 mayo Universitad national de Rosario;

Lazzara M., Riflessioni sulla meritevolezza del consumatore, Rivista diritto fallimentare, 2017, II, pag. 1571;

Regueriro, Las reformas sobre derecho concursal en tiempo de Covid-19, https://auren.com;

Santangeli - Fabbi, Il (giusto) differimento, in ragione dell'emergenza, della entrata in vigore del Codice della crisi d'impresa e dell'insolvenza; ma è indispensabile che alcune norme entrino in vigore immediatamente, Judicium, 2020;

www.bancaditalia.it, Literature Review Issue no. 2, Covid-19 and Economic Analysis: a Review of the Debate, by CaraccioloCingano-Ercolani-Ferrero-Hassan-Papetti-Tommasino. 